UDC 338.124.4:338.483.13.72

DOI: https://doi.org/10.32782/2224-6282/159-21

\author{
Candidate of Economic Sciences, Associate Professor, \\ Lviv Institute of Economics and Tourism \\ ORCID: https://orcid.org/0000-0003-0300-531X
}

Петрук Т. М.

Львівський інститут економіки і туризму

\title{
CRISIS MANAGEMENT MODELS FOR HOSPITALITY INDUSTRY DURING COVID-19
}

Global coronavirus crisis has affected many spheres of economy including the hotel industry. To the larger scale, all travel industry sectors have been heavily affected. As hotel industry is part of economic growth and has a substantial share in world economy, tools need to be developed to create and implement a functionable crisis management model for the hospitality industry worldwide. Unfortunately, current crisis management models which are offered by scientific research have not proven their effectiveness in current situation. Households and economies are left on their own to manage crisis situation and create their own functioning crisis management models. Based on research in the field, we have analyzed the situation and offer tools for creating a working crisis management model for hotels and other accommodation establishments. The article has a practical application and can be used by the hotel operators as guideline.

Keywords: coronavirus, crisis management, hotels, hospitality industry, crisis models.

JEL classification: F01, F23, F47, F62

\section{МОДЕЛІ УПРАВЛІННЯ КРИЗОЮ ДЛЯ СФЕРИ ГОСТИННОСТІ ПІД ЧАС КОВІД-19}

Глобальна коронавірусна криза торкнулася багатьох сфер економіки, включаючи готельну індустрію. У більшому масштабі всі сектори туристичної галузі зазнали сильних наслідків. Оскільки готельна індустрія є частиною економічного зростання і має значну частку у світовій економіці, необхідно розробити інструменти для створення та впровадження функиіональної моделі управління кризовими ситуаціями для індустрії гостинності у всьому світі. Складність коронавірусної кризи в умовах глобальної економіки полягає в першу чергу у тому, шео ї̈ складно оцінити лише з однієї сфери впливу, оскільки поширення коронавірусу в світі спричинило низку менших криз, в тому числі кризу людської свідомості, коли туристи відмовляються подорожувати, вбачаючи у иъьму ризики для свого здоров'я. Крім иього, відсутність практичних моделей управління кризою, які могли б бути використані в даному випадку, лише погіршує ситуащію. На жаль, нинішні моделі антикризового управління, які пропонуються науковими дослідженнями, не довели свою ефективність у сучасній ситуачії. Домогосподарствам та економікам залишається самостійно управляти кризовою ситуачією та створювати власні діючі моделі управління кризовими ситуаціями. Багато компаній на власний ризик створюють моделі виходу із ситуаиії. Однак, запропоновані моделі можуть не підходити готелям різних категорій в залежності від їх розміру, масштабу, або місиезнаходження. Саме тому виникає потреба у виявленні загальних елементів для створення моделі універсального типу, яка могла б слугувати основою для прикладних моделей управління кризою кожним окремим господарським суб' єктом. На основі досліджень у цій галузі ми проаналізували ситуацію та запропонували інструменти для створення діючої моделі управління кризисними ситуаціями для готелів та інших закладів розміщення. Наведено приклади антикризових моделей, що застосовуються готелями вже на даний момент. Проаналізовано пристосованість різних типів антикризових моделей управління до сучасної кризової ситуачії, щчо викликана розповсюдженням коронавірусу у світі. Стаття має практичне застосування і може бути використана готельними операторами як орієнтир.

Ключові слова: коронавірус, управління кризами, готелі, індустрія гостинності, кризові моделі.

Problem statement. In recent year, hospitality industry has undergone tremendous changes which it had never experienced before. Overall restructure of the world economy and limited mobility of people have hindered the industry worldwide, especially hotels and other types of accommodations.

Crisis management models which are typically applied in such cases have not proven their effectiveness. This caused the researchers worldwide to seek for other means to be employed in the creation of international, national and local hotel policies and regulations.

Modern economy is so globalized that the move backwards could not be forecasted at all. And the crisis caused by coronavirus which has been at first seen as temporary problem became not only global crisis but a rather permanent move towards deglobalization of the countries of the world.
All this has left the scientists and researchers of the hospitality industry with an open question of what needs to be done to at least hold the households, not even hoping for improving their current state. The crisis has been so demoralizing for many hotel operators that any method applied within this year only took time and efforts but did not give the expected outcomes.

Purpose of research. This article analyses and looks deeper into the approaches applied in the hotel industry by different countries, showcases the methods used by hotel operators and examines their effectiveness. From the other hand, the article compares current situation with crisis management models in order to propose the model that could be used with some minor amendments to withstand the coronavirus crisis in the hospitality industry for hotels and other types of accommodation facilities. 
The author looks through the literature on the topic and makes own analysis based on several crisis management models to propose a solution to the industry. The findings of the study may have practical meaning to the economies and households within them.

Literature review. According to Alves et al. (2020) citing Coombs, crisis can be defined as "a sudden and unexpected event that threatens to disrupt an organization's operations and poses both a financial and a reputational threat" (p. 2). We often think that crisis is a stage like stagnation through which any organization needs to go through. Although most researchers insist on the unanticipated character of organizational and economic crises.

If companies like hotels could prepare themselves to the situation caused by the spread of coronavirus, there would be probably less tragedy in the whole hospitality industry at this stage. For instance, if the coronavirus was a slow move that the world was leaning to, the hotels would have adapted their premises and mobility arrangements, as well as food hygiene, so that safety and no risk for health would be involved in being accommodated in any country of the entire world.

But unfortunately what happened is a fast and fulminant trend in the hospitality industry which left the hotels at the stage where they had been before, not prepared to accommodating people with social distancing. And this is one of the key reasons why the industry had been so heavily damaged by the coronavirus crisis.

As Khazami et al. (2020) suggest, "the virus epidemic is unforgivable and more serious than expected" (p. 2). Many scientists compare the circumstances of coronavirus crisis to the World War II. It is inevitable that the sectors most affected by the coronavirus outbreak around the world would be suffering decades later until they recover again. According to Ioannides and Gyimothy (2020, p. 624), "the COVID-19 pandemic has halted mobility globally on an unprecedented scale, causing the neoliberal market mechanisms of global tourism to be severely disrupted".

Coronavirus is a very special case. Alves et al. (2020) also agree that due to the unique nature of the coronavirus crisis, all past research data cannot be considered sufficient. Also, the phenomena is very complex and involves so many factors, such as "social phobia, unemployment, supply chain disruption, stock market crashes, economic lockdown, and de-globalization" (Alves et al., 2020, p. 2).

As Katsadze and Milojevic (2020) mention in their thesis, any tiny external problem can trigger tourism and hospitality industry to a great extent. Not to imagine how coronavirus did, and after realizing this fact one can only think of the scale to which the hospitality industry has been really affected.

Research of literature suggests that no travel industry provider had ever developed pre-crisis management means that proved their effectiveness in practice. The talks about the importance of crisis management teams, CMPs (Crisis Management Plans) were nothing but the preparation and creation of typical documents applicable for cases of fires and other typical situations. These documents did not look at a larger scale of the whole economy or business environment which could be protected before the crisis, if companies created adaptation models and could launch them at the crisis early stages. Katsadze and Milojevic (2020) suggest that pre-crisis stages are usually noticeably short as companies are not prepared to them at all and entail containment and damage limitations only.
An interesting fact mentioned by the article by Khazami et al. (2020) is that there are more sectors affected by the troubles in tourism and hospitality industry than we might think. The authors take example of Tunisia, where economy is largely dependent on tourism and look at other sectors. The figures their study finds are astonishing. We already know that hotel industry usually facilitates economic growth and development of country's infrastructure, transportation systems, logistics, service sector like insurance, car rentals, banking and finance, and many more. But this time the example is very practical and tragic at the same time: as tourism and hotel industry are in crisis, the whole economy is in deep crisis, too.

As Alves et al. (2020) argue, "at the firm level, the core of crisis management is to develop strategies that minimize economic loss and increase resilience through a crisis event" (p. 2). In current situation, analysis of the best practices has shown that the investigation of cost structure is necessary. In order to avoid substantial economic loss, hotels and other accommodation facilities need to enter into the stage of savvy costs and only focus on retaining those clients who are ready to travel without thinking how to attract clients in general, as this would be a waste of budgets.

But crisis management models do not offer such options. They rather focus on simple steps like human resources shortages, half business closures and avoidance of all forms of investments. There are hotels which followed this model and for some of them these have proved effective, but it is a matter of hotel size and scale that determines which elements of this model can be applicable to the hotel establishments.

Based on what Alves et al. (2020) find in their research, small firms are the less flexible in coronavirus crisis. However, in our opinion, small firms are usually the most flexible ones in terms of decision making, and they can adapt their policies, prices, supply chain management, and even human resources to the crisis specifics. Large firms, as the authors suggest, have more social responsibility compliance and higher bureaucracy. But we totally disagree with this statement, as usually more bureaucracy and social responsibility compliance simply equals less flexibility.

What is interesting about crisis is that most crisis management models are based on the statement that during crisis the trust to the company is hindered, but in case with coronavirus the people's trust to hotels and accommodations is not hindered. They simply avoid hotels and other types of accommodation, including traveling in general. That is why all the proposed statements by the literature on crisis management that the key focus should be on retaining trust and maintaining reputation are not applicable in the case of current world crisis caused by the spread of coronavirus.

One of the most powerful outcomes of the current coronavirus crisis for the hospitality industry would be changes not only to the households themselves, not to the business side of the industry, but to the scientific research which at the time when it had been most needed proved its inefficiency.

Besides that, COVID-19 is not the first global pandemic which had brought changes to the hospitality industry in recent decades: there were Ebola, SARS and other viruses that affected global mobility. However, seems that nothing has been learned. And for this reason scientists now are full of criticism towards crisis management models and practices and hospitality research in general. 
For instance, Gursoy and G. Chi (2020), argue the following:

"This pandemic is also likely to have a significant impact on the research agenda of hospitality marketing and management scholars. With unprecedented challenges faced by the hospitality industry in the COVID-10 era, hospitality scholars are expected to shift their research focus to develop solutions for the industry. Hospitality scholar will need to provide answers to a number of critical questions such as: what are the customers' sentiments about patronizing a restaurant or a hotel in the time of coronavirus? Are they ready to return? If not, what will make them return?" (p. 528).

Analysis. We have examinted the possible outsomes of coronavirus outbreak for households in general based on the research of Gursoy and G.Chi (2020). After taking into consideration various outcomes proposed by the research insitutes for global economy and some of the local initiatives, we have adapted the model proposed by these researchers. Findings suggest that two of proposed scenarios have most likelihood to occur in the current worldwide crisis situation. Other scenarios have not proven to be real in current economic terms and in arrordance to the research consucted by the authors. These are the figures obtained from structured analysis:

According to the scenarios proposed by Krishnan et al. (2020) in their study, smaller hotels will recover faster than the luxury hotels and larger hotel chains. This is due to the lower operating costs and overall better demand for low- er-priced rooms. Also, as we believe, smaller hotels like private apartments offer less social contacts as there are few if no public zones and large reception areas.

Exhibit 2 describes the key facilities that would be needed by the tourists who stay at hotels after COVID-19 outbreak slows down:

Many companies are now intending to promote their practical advice on COVID-19 action plan for hotels and other accommodation facilities. The key points here are the focus on domestic travel, increasing the length of stays, promoting premium room types which are bigger in size, utilizing personalization, and others. All these strategies are quite logical in the time of coronavirus, but the question remains for the researchers: why and how could long-term research on crisis management not offer businesses a good set of pre-crisis management practices that would not lead to hotels businesses damaged and in many cases destroyed by the outbreak of global virus? Now business operators and consulting companies are seeking to offer their advice, their practices, they share knowledge of the situation and try to help others by own example. But nothing from the past science and research which could be more or less adaptable to the current coronavirus outbreak and its impact on the hotel industry. As Bhattacharya (2020) mentions, we are now talking about the fundamental issues in the hotel industry which may affect sales and marketing in the long run: a complete rebuilding of the customer experience which will entail new forms of customer perceptions. The author argues that "after the epidemic, customers will

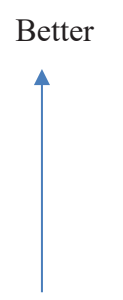

Virus spread and publicheath response Effectivenes $\mathrm{s}$ of publichealth response

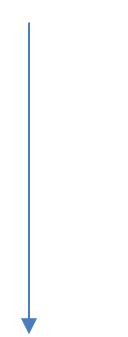

Pandemic escalation; prolonged downturn without recovery

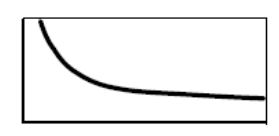

Worse

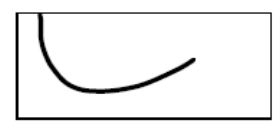
full recovery
Virus contained but Virus contained growth sector damage; lower returns long-term trend growth

Virus recurrence; slow long-term growth, no
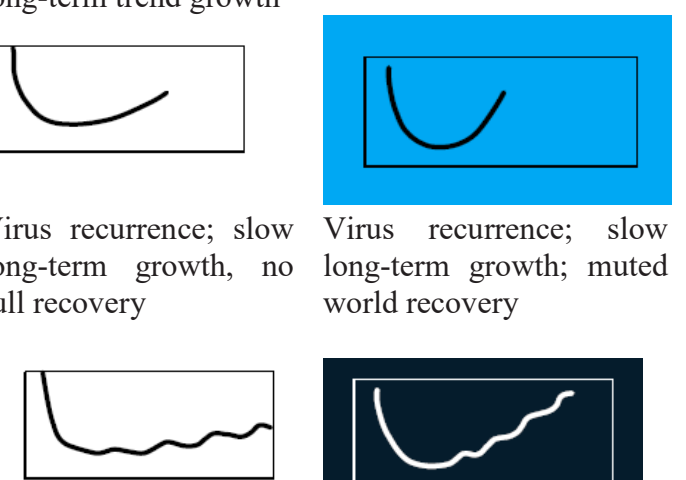

Virus recurrence; slow long-term growth; muted world recovery

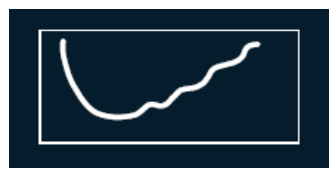

Pandemic escalation; low progression towards economic recovery

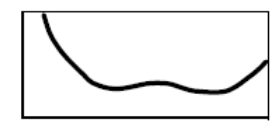

Ineffective
interventions
Virus contrained; strong growth rebound

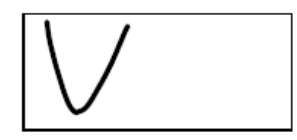

Virus recurrence; return to trend growth;strong world rebound

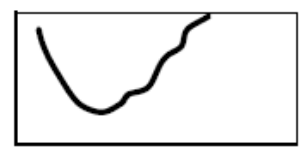

Pandemic escalation; delayed but full economic recovery

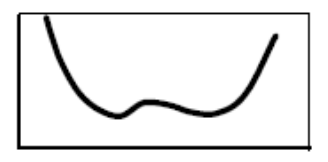

Partially effective Highly effective interventions interventions Better

Figure 1. Two possible scenarious about COVID-19 crisis GDP impact of COVID-19 spread, public-health response, and economic policies

Source: McKinsey (2020, p. 79) 


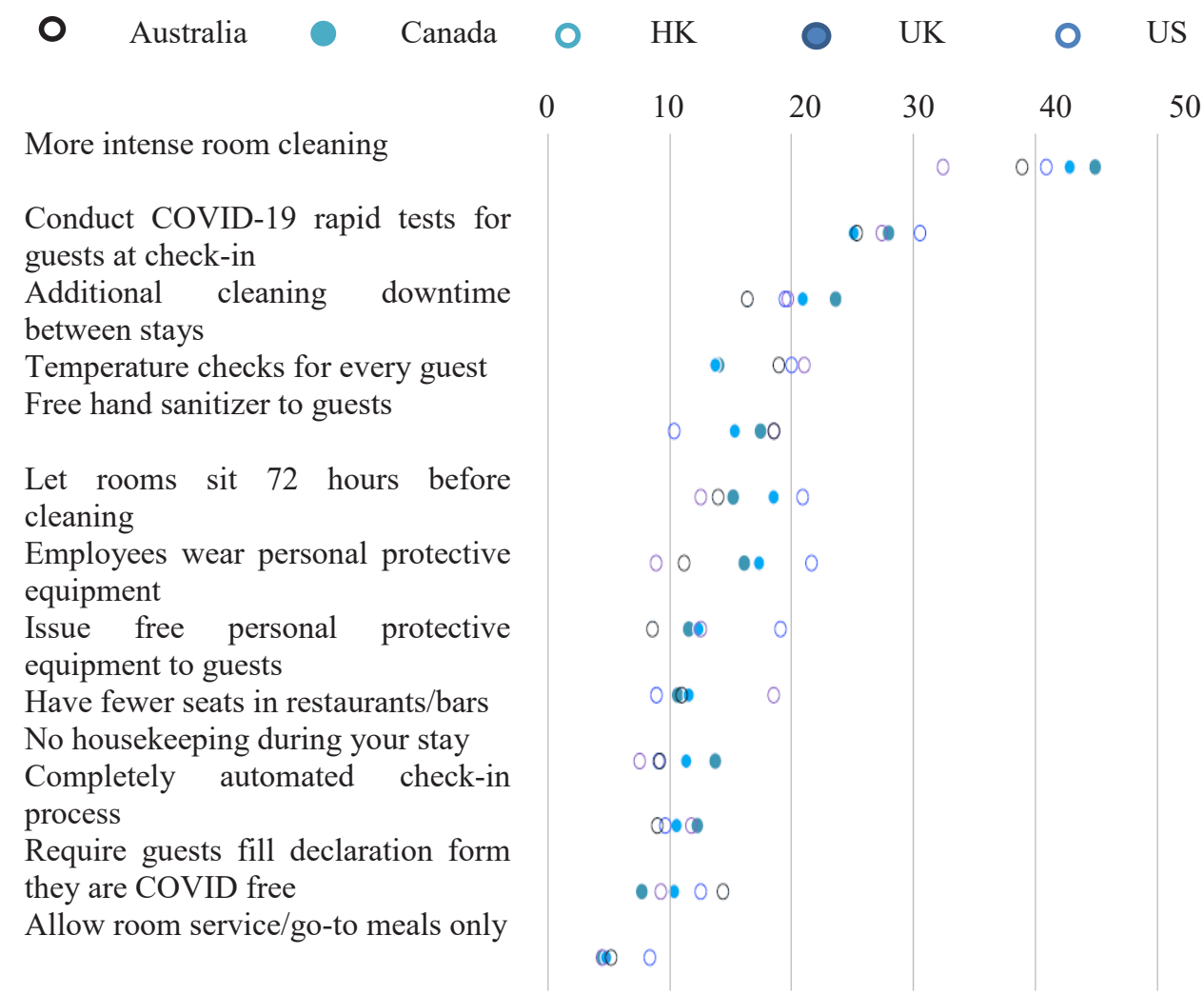

Figure 2. Actions hotels could take to help protect guests from coronavirus, $\%$ of respondents Source: McKinsey (2020, p. 21)

pay more attention to the safety of food choices" (para. 9). Hotels will need to fully rebuild their marketing towards more safety and hygiene. Forget fancy design and in-room bathtub as travelers after coronavirus will be more concerned with the clarity of materials and their safety than before. Voitika (2020) also stresses that even marketing budgets need to be readdressed towards metasearch and cites Chetan Patel who believes that "if a user is looking at your property on metasearch, they already have the intent to book. Invest more on search and metasearch to capture as many of these high-intent customers as possible and lead them to your hotel website" (para. 6).

There are two extremely critical factors for lessening the effects of coronavirus on the hotel industry worldwide: training the resilient workforce and correct government communication. As mentioned by Khazami et al. (2020) in their article, these means are important as they have direct impact on the worldwide tourist mobility. They argue that we now "need to develop creative and inventive employment solutions to ensure the resilience of the workforce after decades of precariousness" (Khazami et al., 2020, p. 3). From the other hand, government needs to be clear yet not limiting in their analysis of the current situation. Many governments are now speculating on the coronavirus outbreak, some seeking money like Ukraine, others trying to put themselves in worse situation like Spain and Italy to avoid paying to the EU. Germany, for instance, intends to keep all the tourist money within the country to maintain its economic power in post-crisis period. For this reason, so many Germans are advised not to travel abroad as it is very unsafe, which is not true at all.

Ioannides and Gyimothy (2020) provide example that there are various approaches towards how coronavirus out- break in the global hospitality industry will affect the future of the industry. From one hand, it is believed that it may fully and radically change travel patterns of people. But from the other hand the authors provide example of studies which argue that the industry, despite the serious crises it experiences in last two centuries always bounced back.

According to Khazami et al. (2020, p. 3), "the crisis is a privileged opportunity to set up governance models with an intersectoral dimension between the key players in tourism and culture". Governments need to become mediums of information sharing who can be trusted, not doubted.

Findings. Study suggests that the following are the critical elements of the crisis management model which can be applied by hotels and other types of accommodation facilities in the course of global coronavirus crisis independently of the hotel size, scale, and location:

Flexibility is a crucial part of any crisis management. Authors on crisis management argued for the past ten years that anti-crisis teams and intelligence systems need to be developed, companies have to be prepared for the times of crises, but the only important part for a situation like we currently have is fast and flexible decision making. Ability to adjust hotel prices fast are is important. As Alves et al. (2020) further mention, "timely communication at the management level is essential during crises" (p. 4). Katsadze and Milojevic (2020) also believe that "reliable and quick decisions are crucial when dealing with unexpected crisis and system collapse" (p. 4).

This means that each organization in its internal structure usually has mechanisms for fast reaction towards any type of external changes. Hotels as mechanisms can be different. Bigger hotels usually have higher hierarchy and for 
this reason need more time for the decision to go through. Smaller hotels, on the contrary, have less hierarchy and can be quicker in their decision-making process. Overall flexibility is highly grounded on this aspect. Without hotels' ability to make decisions in fast changing business environment, no accommodation establishment can be flexible in other modifications in periods of crisis.

Innovation and new technologies have always proven helpful in times of economic changes and challenges. As crisis is a fast change that requires adaptation, the application of innovative methods is a good practice. Alves et al. (2020) mention practices pointed out by Tang and Nong, it has been found that "social media is widely used as a channel for effective crisis communications by professionals and management" (p. 4). Sharing knowledge using the fastest and most engagement provoking methods like social media is a wonderful tool for crisis management practices. Of course, this method has been rather new and at times of coronavirus rather practically applicable than described by the theory and research, but in some five years when the crisis passes, researchers will add it to the best methods and recognize its effectiveness.

Customization is also an interesting factor of crisis management which has been seen as applicable for the hotel industry in the coronavirus summer season of 2020. As Alves et al. (2020) believe, "robustness and flexibility are highly demanding when managing transboundary crises" (p. 4). Companies that were able to customize their services, hotels that started catering for the upcoming needs of coronavirus travelers, accommodation that became more secure than ever before have won the game this summer.

Internal leadership as a whole, not just flexibility, can be also examined apart from other important issues in crisis management for hotels. Katsatze and Milojevic (2020) believe that "during the crisis management phase, scholars describe the flexibility of organizational structures and the leadership skills of the managers as important internal factors for successful actions" (p. 4). More researchers believe in leaders in crisis management than models. Some suggest that there are a set of features and characteristics of leaders that can best lead organizations at times of crises.
Conclusions. Hotel industry will not recover on its own. Of course, the aspects listed in this article which we named critical are to be considered. Undoubtedly, assistance from the government and resilient workforce are needed to facilitate the reopening of many hotels and accommodation types. But the crucial point is the client experience and demand for travel which has been hindered deeply. According to Gursoy and G. Chi (2020), "since the breakeven point in the hospitality industry is relatively high due to high operating costs, the survival of many hospitality businesses heavily depends on increasing the demand for their services and products" (p. 528). Without people wanting to travel and stay at the hotels, without them being sure that hotels are a safe place to be, without news and information from mass media that traveling is easy and safe again this would not be possible to achieve. As Gursoy and G. Chi (2020) further imply, "the industry and the academia are in urgent need of behavioral and operational hospitality marketing and management research to guide the hospitality operations in the time of COVID-19 pandemic" (p. 529).

Ioannides and Gyimothy (2020) raise an important issue in their article: the impact that coronavirus outbreak had shown to the world that has been slowed down for several month and which consequences it had on the state of our global ecosystem. This is a powerful tool now in the hands of policymakers and even at the level of smaller households such as hotels, the consequences of coronavirus can be taken positive and as a good lesson to learn: hotels can apply social sustainability practices at their local level, but if trend continues to grow, this can bring a lot of change to the world in the future.

In general, the application of the above mentioned principles together with the adaptation of the practices offered by other hotels and practitioners in the field is a good combination towards creating a stable crisis management model which would serve well in the current coronavirus crisis situation. But it is necessary to understand that without pre-crisis management planning and post-crisis management analysis withstanding coronavirus would only become a temporary hospitality industry downturn.

\section{References:}

1. Alves, Jose C., Lok, Tan Cheng, Luo, YuBo, \& Hao, Wei (2020) Crisis Management for Small Business during the COVID-19 Outbreak: Survival, Resilience and Renewal Strategies of Firms in Macau. Researchsquare. URL: https://assets.researchsquare.com/ files/rs-34541/v1/89be2a22-6732-4e73-91f4-4c02ce2e7785.pdf (accessed October 07, 2020).

2. Bhattacharya, Avik (2020) Hospitality Industry After Covid-19: How to Survive? EHL Insights. Ecole Hoteliere de Lausanne. URL: https://hospitalityinsights.ehl.edu/hospitality-covid19-crisis (accessed October 07, 2020).

3. Gursoy, Dogan, \& G. Chi, Christina (2020) Effects of COVID-19 pandemic on hospitality industry: review of the current situations and a research agenda. Journal of Hospitality Marketing and Management, vol. 29(5), pp. 527-529. URL: https://www.tandfonline.com/ doi/full/10.1080/19368623.2020.1788231; doi. 10.1080/19368623.2020.1788231 (accessed October 07, 2020).

4. Ioannides, Dimitri, \& Gyimothy, Szilvia (2020) The COVID-19 crisis as an opportunity for escaping the unsustainable global tourism path. Tourism Geographies, vol. 22(3), pp. 624-632. URL: https://www.tandfonline.com/doi/full/10.1080/14616688.2020.1763445, doi: 10.1080/14616688.2020.1763445 (accessed October 07, 2020).

5. Katsadze, Beka, \& Milojevic, Daniel (2020) Social Sustainability in COVID-19 Crisis: The Case of the Hotel Industry. Master Thesis. Uppsala University, Gotland. URL: http://www.diva-portal.org/smash/get/diva2:1441677/FULLTEXT01.pdf (accessed October 07, 2020).

6. Khazami, Nesrine, Lakner, Zoltan, \& Nefzi, Ayoub (2020) Pandemic and tourism: Re-preparation of tourism post COVID-19. Journal of Hotel and Business Management, vol. 9, 198. URL: https://www.longdom.org/open-access/pandemic-and-tourism--repreparation-of-tourism-post-covid-19.pdf; doi: 10.35275/2169-0286.20.9.198 (accessed October 07, 2020).

7. Krishnan, Vik, Mann, Ryan, Seitzman, Nathan, \&Wittkamp, Nina (2020) Hospitality and COVID-19: How long until 'no vacancy’ for US hotels? McKinsey\&Company. Travel, Logistics \& Infrastructure Practuce. URL: https://www.mckinsey.com/ / media/McKinsey/Industries/Travel\%20Transport\%20and\%20Logistics/Our\%20Insights/Hospitality\%20and\%20COVID\%2019\%20 How\%20long\%20until\%20no\%20vacancy\%20for\%20US\%20hotels/Hospitality-and-COVID-19-How-long-until-no-vacancy-forUS-hotels-vF.pdf (accessed October 07, 2020).

8. Voitika, Alisa (2020) Hotels in crisis can still win: how to adjust strategies without jeopardizing your future. Triptease. URL: https://triptease.com/blog/hotels-coronavirus-crisis-strategy/ (accessed October 07, 2020). 